\title{
Investigation of Indoor Stability Testing of Polymer Solar Cell
}

\author{
Pelin Kavak $^{1}$ and Elif Alturk Parlak ${ }^{2}$ \\ ${ }^{1}$ Department of Physics, Faculty of Arts and Science, Yildiz Technical University, Davutpasa Campus, Esenler, 34210 Istanbul, Turkey \\ ${ }^{2}$ Scientific and Technological Research Council of Turkey (TÜBİTAK) Marmara Research Centre (MAM), Material Institute, \\ Gebze, 41470 Kocaeli, Turkey \\ Correspondence should be addressed to Elif Alturk Parlak; elif.parlak@tubitak.gov.tr
}

Received 29 April 2016; Accepted 25 October 2016

Academic Editor: Ulrich Maschke

Copyright (C) 2016 P. Kavak and E. Alturk Parlak. This is an open access article distributed under the Creative Commons Attribution License, which permits unrestricted use, distribution, and reproduction in any medium, provided the original work is properly cited.

We have fabricated organic solar cell of a new low bandgap polymer poly[4,4-bis(2-ethylhexyl)-4H-cyclopenta[2,1-b:3,4$b^{\prime}$ ]dithiophene-2,6-diyl-alt-4,7-bis(2-thienyl)-2,1,3-benzothiadiazole-5' $5^{\prime \prime}$-diyl] (PCPDTTBTT). We have investigated for the first time the stability tests, ISOS-L-1 and ISOS-D-3, of PCPDTTBTT solar cells. Thermal annealing of PCPDTTBTT solar cells at $80^{\circ} \mathrm{C}$ brought about an improvement of photocurrent generation, stability, and efficiency of the solar cells. $T_{80}$ value of PCPDTTBTT solar cell is about 150 hours which is close to P3HT (235 h). PCPDTTBTT is very promising polymer for both polymer solar cell efficiency and stability.

\section{Introduction}

Polymer solar cells (PSCs) are currently attracting a great deal of attention having already shown great promise as renewable, lightweight, and low cost energy sources [1-3]. In a molecular LEGO game, many combinations are possible for donor (D) and acceptor (A) building blocks; novel low bandgap polymers are generated and subsequently characterized. Development of low bandgap polymers can be achieved with the selection of suitable D and A segments in molecular design. Donor-donor-acceptor-donor structure (DDAD) is well known for low bandgap polymer. That structure has some solubility problems which can be improved by introducing substitution of alkyl chains. PCPDTTBTT is one of the DDAD structure copolymers. In the literature effects of position of side chains on PCPDTTBTT solar cell were studied (thin solid films). In addition PCPDTTBTT solar cells with nanocrystal quantum dots were studied [4-6].

In spite of high development potential of polymer solar cells, their stability and degradation are not studied in detail. The intrinsic reasons of degradation of organic photovoltaic are poorly understood. Studies have indicated that the degradation mechanisms in polymer solar cells include reaction with $\mathrm{O}_{2}, \mathrm{H}_{2} \mathrm{O}$, and the electrode materials. Therefore, to increase the durability of polymer solar cells requires careful selection of donor, acceptor, electrode, and encapsulation materials $[7,8]$.

There are many parameters affecting the stability of organic solar cell. Material is very important; that is, glass transition temperature $\left(T_{\mathrm{g}}\right)$, molecular weight, HOMOLUMO levels, and stability of polymer are very critical. Encapsulation methods mostly use UV-epoxy resins, some barrier films, and so forth, during fabrication process. The choice of encapsulation method is crucial to improve stability of solar cells. Annealing is a parameter where polymer can be annealed thermally or by solvent annealing. Architecture is also prominent which can be of normal or inverted type that leads to affecting the stability of organic solar cell.

Encapsulated organic solar cells based on small molecules (pentacene $/ \mathrm{C}_{60}$ ) were studied based on their shelf life [9]; the devices were stable over $6000 \mathrm{~h}$, while devices with no encapsulation degraded rapidly after only $10 \mathrm{~h}$ of air exposure. In addition, thermal annealing during fabrication of the devices improved the open-circuit voltage and power conversion efficiency of the solar cells. Krebs and Spanggaard [10] also studied stability of polymer solar cells, and the lifetime of polymer solar cells over $10,000 \mathrm{~h}$ was achieved. However, the device performance is too low. 


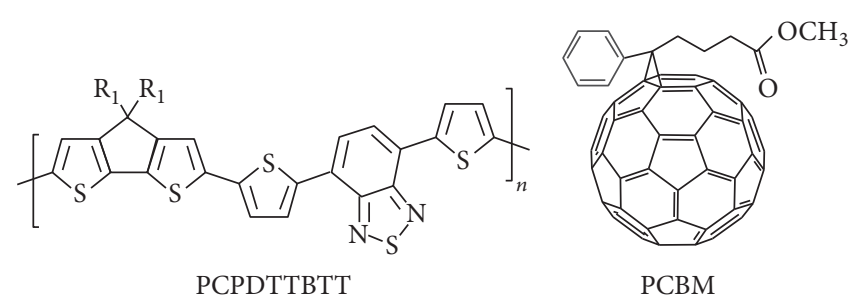

FIgURE 1: Chemical structure of PCPDTTBTT and $\mathrm{PC}_{61} \mathrm{BM}$.

OPV systems may have failure modes other than inorganic systems including photooxidation and chemical degradation of the electrodes and interfaces [11]. For this reason, a new set of guidelines are being developed, which aim to compare data and claims obtained by different laboratories. The complexity of developing testing procedures to measure durability stems from the fact that unlike inorganic technologies organic photovoltaic is a highly diverse technology with cells that can be prepared with different architecture, using many different materials. All these variables affect overall stability performance of the final device. Enhancement of stability of organic photovoltaic can be achieved through packaging and encapsulation or other means that empirically remove the problem or reduce it as much as possible. To figure out the problem, a plot of the power conversion efficiency over time can be taken before ending with device degradation. The time of operation until $80 \%\left(T_{80}\right)$ and $50 \%$ $\left(T_{50}\right)$ of the initial performance is extracted for a device exhibiting a linear decay. An agreement has to be made on how decay data have to be evaluated and reported. For that reason, the guidelines of OPV stability protocols have been presented in ISOS meetings [12]. The purpose is to provide reasonable accuracy in the comparison of reported stability and lifetime data for organic solar cells produced from polymers and small molecules.

Significant progressing polymer solar cells have been made by the synthesis of low bandgap conjugated polymers and optimization of the device preparation conditions, including the application of adjusting the volume fractions of the components $[1,13]$, thermal annealing treatments $[14,15]$, and solvent annealing $[16,17]$.

The commercialization of polymer solar cells needs greatly the understanding of the degradation phenomena such as recrystallization and temperature variations, as well as reactions during oxidation and reduction. The understanding of degradation mechanism will lead to the development of novel materials, efficient polymer solar cells encapsulation, and the alternative barrier layers which are more resistant to oxygen and water.

In this study, we investigate new low bandgap polymer PCPDTTBTT that is not studied in detail in literature. We have firstly studied stability testing of PCPDTTBTT solar cells, ISOS-L-1 and ISOS-D-3. PCPDTTBTT is very promising polymer for both polymer solar cell efficiency and stability.

\section{Experimental}

2.1. Materials. PCPDTTBTT donor material (Figure 1) was purchased from Luminescence Coop. Hole transport layer, poly(3,4-ethylenedioxythiophene) (PEDOT) doped with poly(styrene sulfonic acid) (PSS) (PEDOT:PSS Clevios P), w as obtained from Heraeus and n-type semiconductor phenyl$\mathrm{C}_{61}$-butyric acid methyl ester $\left(\mathrm{PC}_{61} \mathrm{BM}\right)$ was purchased from Sigma-Aldrich (Figure 1). PCPDTTBTT and PCBM solutions with $20 \mathrm{mg} / \mathrm{mL}$ concentration were prepared by using 1,2-dichlorobenzene from Alfa Aesar. The active layer solutions were prepared by mixing the PCPDTTBTT polymer and PCBM in 1:3 blend ratio.

2.2. Fabrication of Polymer Solar Cells. PCPDTTBTT devices were fabricated on glass substrates with the following st ructure: indium thin oxide (ITO)/PEDOT:PSS/PCPDTTBTT: $\mathrm{PC}_{61} \mathrm{BM} / \mathrm{Ca} / \mathrm{Al}$. The ITO coated glass substrates with sheet resistance of $15 \Omega /$ sq. were ultrasonically cleaned in detergent, acetone, isopropyl alcohol, and deionized water, successively for $5 \mathrm{~min}$, and then dried under nitrogen flow. The dried ITO substrates were transferred into an UV-ozone cleaner to create a hydrophilic ITO surface. PEDOT:PSS solution was spin-coated onto glass substrates and annealed at $130^{\circ} \mathrm{C}$ for $10 \mathrm{~min}$.

Then the blends were spin-coated onto the PEDOT:PSS coated substrates (Figure 2) and annealed at different temperatures of $80^{\circ} \mathrm{C}, 100^{\circ} \mathrm{C}$, and $120^{\circ} \mathrm{C}$ for $10 \mathrm{~min}$. Finally, $\mathrm{Ca}(10 \mathrm{~nm}) / \mathrm{Al}(70 \mathrm{~nm})$ was deposited by thermal vacuum evaporation in a vacuum of about $1 \times 10^{-6} \mathrm{mbar}$. The active area of the cell was $0.09 \mathrm{~cm}^{2}$. The encapsulation of the polymer solar cell was performed by using Osilla UV curing epoxy resin.

2.3. Characterization. The current density-voltage $(J-V)$ characteristics of devices were taken under light illumination using standard solar irradiation of $100 \mathrm{~mW} / \mathrm{cm}^{2}$ (AM 1.5G) with xenon lamp as a light source and computer-controlled voltage-current Keithley 2600 source meter at $25^{\circ} \mathrm{C}$ under ambient atmosphere. Morphology of the blend films was investigated with noncontact mode by Atomic Force Microscopy (AFM) (Park Systems). UV-Vis spectroscopic measurements were performed by using a PG Instruments $T_{80}$ model UV-Vis spectrophotometer. 
TABLE 1: Effects of thermal annealing of PCPDTTBTT solar cells on photovoltaic parameters.

\begin{tabular}{lcccc}
\hline PCPDTTBTT solar cells & $V_{\mathrm{OC}}(\mathrm{V})$ & $J_{\text {SC }}\left(\mathrm{mA} / \mathrm{cm}^{2}\right)$ & FF & $0.38 \pm 0.01$ \\
No annealing & $0.58 \pm 0.01$ & $4.83 \pm 0.5$ & $0.39 \pm 0.01$ & $1.08 \pm 0.08$ \\
Thermal annealing at $80^{\circ} \mathrm{C}$ & $0.59 \pm 0.01$ & $5.71 \pm 0.5$ & $0.37 \pm 0.01$ & $1.34 \pm 0.08$ \\
Thermal annealing at $100^{\circ} \mathrm{C}$ & $0.60 \pm 0.01$ & $4.81 \pm 0.5$ & $0.39 \pm 0.01$ & $1.08 \pm 0.08$ \\
Thermal annealing at $120^{\circ} \mathrm{C}$ & $0.61 \pm 0.01$ & $5.45 \pm 0.5$ & $1.30 \pm 0.08$ \\
\hline
\end{tabular}

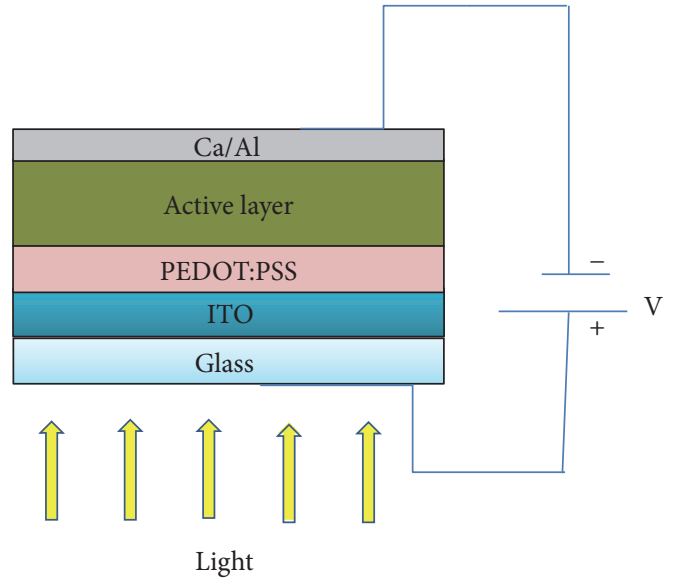

FIgURE 2: Device architecture of polymer solar cell.

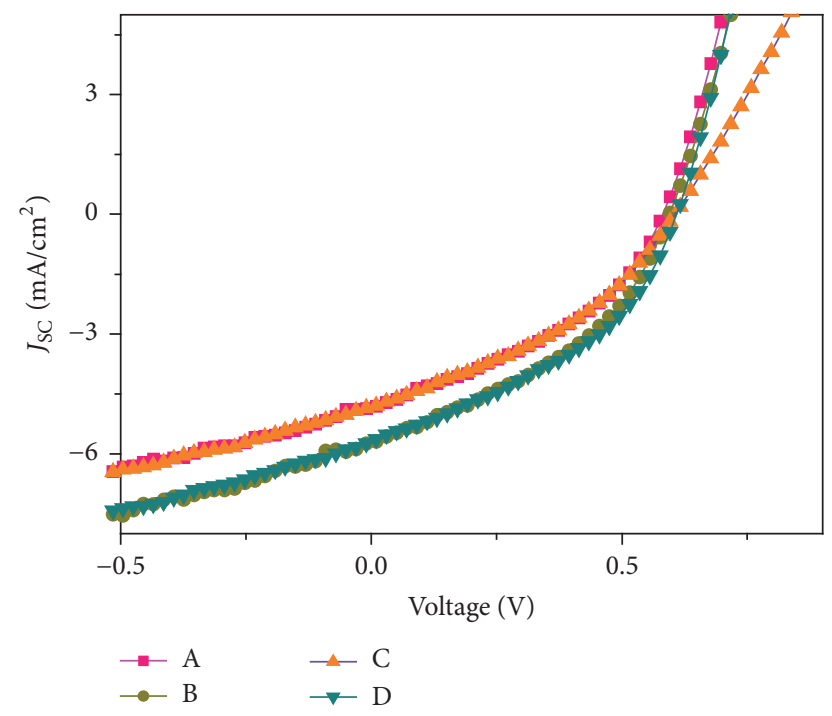

Figure 3: Current density and voltage characteristics of PCPDTTBTT solar cells: A: without thermal annealing, B: thermal annealing at $80^{\circ} \mathrm{C}, \mathrm{C}$ : thermal annealing at $100^{\circ} \mathrm{C}$, and $\mathrm{D}$ : thermal annealing at $120^{\circ} \mathrm{C}$.

\section{Results and Discussion}

PCPDTTBTT devices which were fabricated on glass substrates and indoor stability of the polymer solar cells were studied. Current density-voltage characteristics of PCPDTTBTT solar cells were depicted in Figure 3. Effect of annealing was investigated on PCPDTTBTT solar cells. Table 1 summarizes effects of thermal annealing of PCPDTTBTT

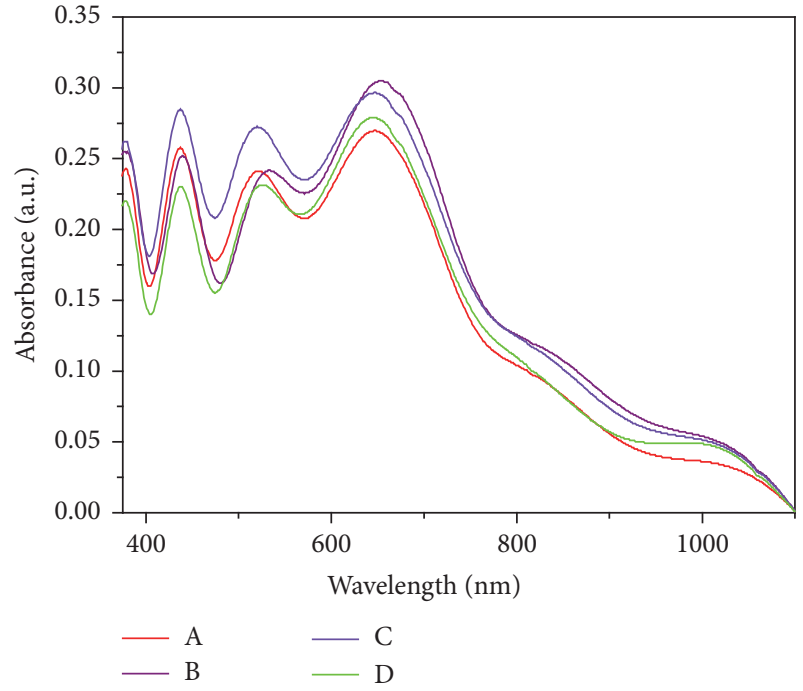

FIgURE 4: UV spectra of PCPDTTBTT:PCBM blend films on glass substrate: A: without thermal annealing, $\mathrm{B}$ : thermal annealing at $80^{\circ} \mathrm{C}, \mathrm{C}$ : thermal annealing at $100^{\circ} \mathrm{C}$, and $\mathrm{D}$ : thermal annealing at $120^{\circ} \mathrm{C}$.

solar cells on photovoltaic parameters. Thermal annealing provided improvement of current density of PCPDTTBTT solar cells. When PCPDTTBTT solar cell was annealed at $80^{\circ} \mathrm{C}$, the current densities and power conversion efficiencies of PCPDTTBTT solar cells increased compared to PCPDTTBTT solar cell without annealing (Figure 3 ). The effects of annealing temperature on PCPDTTBTT solar cells were summarized in Table 1.

UV spectra of PCPDTTBTT:PC ${ }_{61} \mathrm{BM}$ blend films are seen in Figure 4. It is observed that considering the absorption of PCPDTTBTT:PC ${ }_{61} \mathrm{BM}$ blend films there are two absorbance maxima which are 518 and $643 \mathrm{~nm}$. Absorption of all PCPDTTBTT:PC ${ }_{61} \mathrm{BM}$ blend films with thermal annealing indicated that absorption values are enhanced which means that photon harvesting increased. Furthermore, annealing also leads to red shift $(645 \mathrm{~nm}-657 \mathrm{~nm})$ in the $\mathrm{UV}$ absorbance maxima which means conjugation length is increased.

IPCE values of PCPDTTBTT solar cells with various annealing temperatures which were fabricated at $80^{\circ} \mathrm{C}, 100^{\circ} \mathrm{C}$, and $120^{\circ} \mathrm{C}$ are presented in Figure 5. The best result for photocurrent generation was obtained in PCPDTTBTT solar cells with thermal annealing at $80^{\circ} \mathrm{C}$. All thermal annealing conditions indicated that thermal annealing improved photocurrent generation (Figure 5). IPCE plot showed that the photocurrent generation at $80^{\circ} \mathrm{C}$ is greater than in the other 


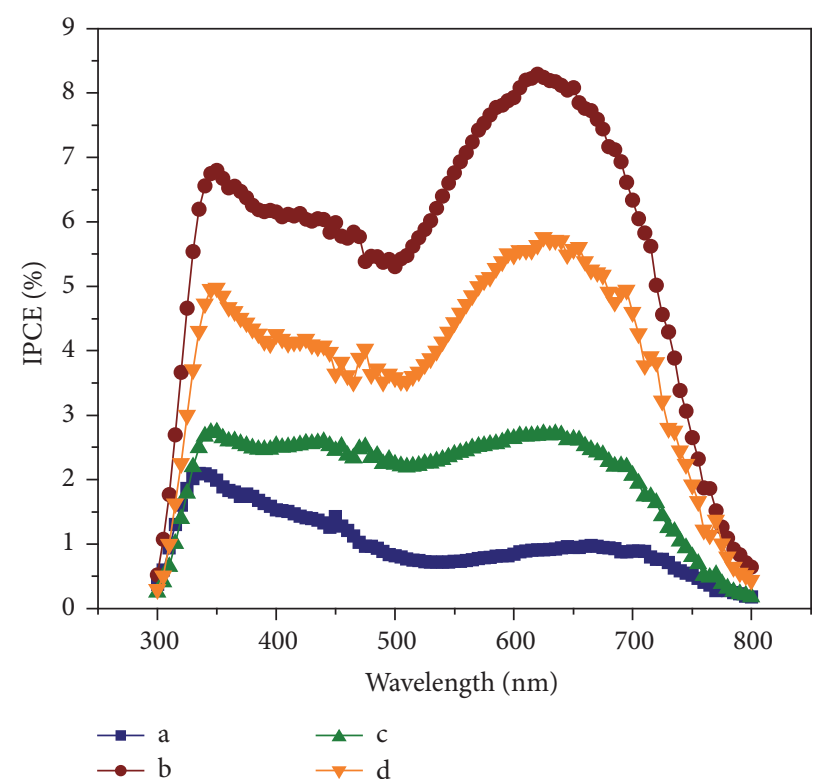

FIGURE 5: IPCE plot of PCPDTTBTT:PCBM solar cells: A: without thermal annealing, B: thermal annealing at $80^{\circ} \mathrm{C}, \mathrm{C}$ : thermal annealing at $100^{\circ} \mathrm{C}$, and $\mathrm{D}$ : thermal annealing at $120^{\circ} \mathrm{C}$.

temperatures. IPCE and $J$ and $V$ results indicated that the optimum temperature for annealing seems to be at $80^{\circ} \mathrm{C}$.

3.1. Stability Tests of PCPDTTBTT Solar Cells. There are several categories of stability testing of OPV devices such as tests under dark, simulated light, and humidity and at outdoor conditions. Each degradation test [18] is divided into three categories: basic (1), intermediate (2), and advanced (3) levels. The main variables of the experiments are temperature, light, humidity, and environment. In this study, the solar cells were tested with ISOS-L-1 and ISOS-D-3 testing protocols.

For accurate comparison of indoor stability testing in real life, a light source that closely matches spectral distribution of day light has to be chosen. Xenon arc is very good match to AM 1.5G with correct filter. Since lamp aging tends to affect more the UV range than other ranges, monitoring in UV range is critical to maintain proper irradiance level. For indoor testing, ISOS-L-1 [12] was carried out to understand degradation of organic solar cells. The brief history of testing protocols was given in Table 2.

Device structure is ITO/PEDOT:PSS/PCPDTTBTT:PCBM/ $\mathrm{Ca}$ Al. There was no annealing during fabrication of PCPDTTBTT. For this device ISOS-L-1 testing (Figure 6(a)) indicated that the normalized $V_{\mathrm{OC}}$ is very stable during $500 \mathrm{~h}$; however normalized $J_{\mathrm{SC}}$ decreased to $40 \%$ durability. After $100 \mathrm{~h}$, efficiency decreased to $50 \%$ durability; it was very significant change, and then it decreases slightly. After $400 \mathrm{~h}$, the efficiency decreased gradually to $20 \%$ durability.

Stability of $V_{\text {OC }}$ values of PCPDTTBTT solar cell was investigated in Figure 6(a). It is showed that all devices showed very good stability in respect to $V_{\mathrm{OC}}$. Meanwhile with PCPDTTBTT solar cell $80^{\circ} \mathrm{C}$ thermal annealing indicated $100 \%$ durability in $500 \mathrm{~h}$ under AM $1.5 \mathrm{G}$ solar simulator.
TABLE 2: Properties of ISOS-L-1 and ISOS-D-3 protocols.

\begin{tabular}{lcc}
\hline & ISOS-L-1 & ISOS-D-3 \\
\hline Light source & Simulator & None \\
AM 1.5G & $65^{\circ} \mathrm{C}$ \\
$\begin{array}{l}\text { Remperature } \\
\text { Ambive humidity }\end{array}$ & Ambient (low) & $85 \%$ (chamber) \\
$\begin{array}{l}\text { Characterization light } \\
\text { source }\end{array}$ & Solar simulator & Solar simulator \\
\hline
\end{tabular}

Normalized $J_{\mathrm{SC}}$ plot shows that stability of PCPDTTBTT solar cell $80^{\circ} \mathrm{C}$ thermal annealing is the best one since current density stability is $70 \%$ in 500 hours under AM 1.5G solar simulator (Figure 6(b)). Stability of PCPDTTBTT solar cell $100^{\circ} \mathrm{C}$ thermal annealing is also better than others. It is about $60 \%$ durability of normalized $J_{\mathrm{SC}}$ (Figure 6(b)). Stability of FF of PCPDTTBTT solar cell is affected by annealing conditions (Figure 6(c)). The device structure with $80^{\circ} \mathrm{C}$ thermal annealing showed the best FF values which are $70 \%$. In 500 hours under AM 1.5G solar simulator when it is increased to $120^{\circ} \mathrm{C}$, stability of FF of PCPDTTBTT solar cell decreased to $50 \%$ in $500 \mathrm{~h}$ under AM $1.5 \mathrm{G}$ solar simulator (Figure 6(c)). Figure 6(d) depicted that PCPDTTBTT solar cell with thermal annealing at $80^{\circ} \mathrm{C}$ has $50 \%$ durability in $500 \mathrm{~h}$.

ISOS-D-3 stability testing of PCPDTTBTT indicated that two devices showed very good stability with respect to $V_{\mathrm{OC}}$. The former is PCPDTTBTT solar cell without thermal annealing and the latter is PCPDTTBTT solar cell with $80^{\circ} \mathrm{C}$ thermal annealing. Normalized $J_{\mathrm{SC}}$ and time plot of ISOS-D-3 testing showed $50 \%$ durability in 400 hours for PCPDTTBTT solar cell without thermal annealing and stability of PCPDTTBTT solar cell at $80^{\circ} \mathrm{C}$ thermal annealing (Figure 7(b)). Normalized efficiency and time plot of ISOS-D3 study of PCPDTTBTT solar cell is depicted in Figure 7(d). It is indicated that stability of PCPDTTBTT solar cell without thermal annealing and stability of PCPDTTBTT solar cell with $80^{\circ} \mathrm{C}$ thermal annealing are very close to each other and also have higher durability than stability of PCPDTTBTT solar cell with $100^{\circ} \mathrm{C}$ and $120^{\circ} \mathrm{C}$ thermal annealing.

It is concluded that when PCDTTBTT film is annealed at higher temperatures that can cause some detrimental effect in the film, these places, for example, some dark points, can lead to faster degradation and so decrease the device performance. These dark points can be seen in AFM images in Figure 8(d).

PCPDTTBTT:PCBM blends were spin-coated onto the glass substrates and annealed at different temperatures of $80^{\circ} \mathrm{C}, 100^{\circ} \mathrm{C}$, and $120^{\circ} \mathrm{C}$ for $10 \mathrm{~min}$. AFM pictures have been taken and compared with respect to morphology. AFM photographs of PCPDTTBTT:PCBM blends at annealed different temperatures of $80^{\circ} \mathrm{C}, 100^{\circ} \mathrm{C}$, and $120^{\circ} \mathrm{C}$ for $10 \mathrm{~min}$ are depicted in Figure 8. Roughness of the film without annealing was about $3.75 \pm 0.5 \mathrm{~nm}$. AFM of PCPDTTBTT:PCBM blends without annealing indicated that the grain sizes are about $90 \pm 5 \mathrm{~nm}$; there are also small dark spots. The roughness of PCPDTTBTT:PCBM blends with $80^{\circ} \mathrm{C}$ annealing is about $4.00 \pm 0.5 \mathrm{~nm}$ and the grain size is about $100 \pm$ $5 \mathrm{~nm}$ (Figure $8(\mathrm{~b})$ ). AFM of PCPDTTBTT:PCBM blends at 


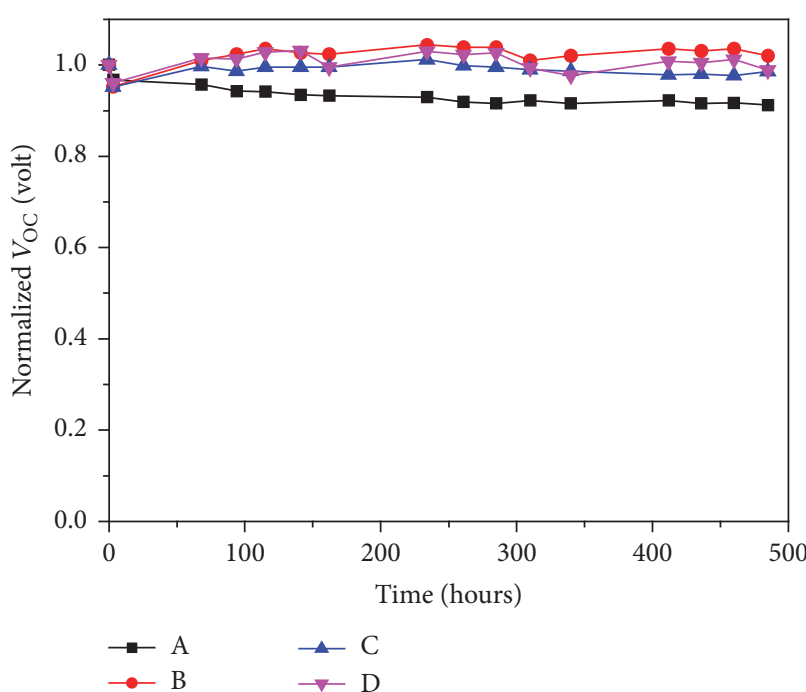

(a)

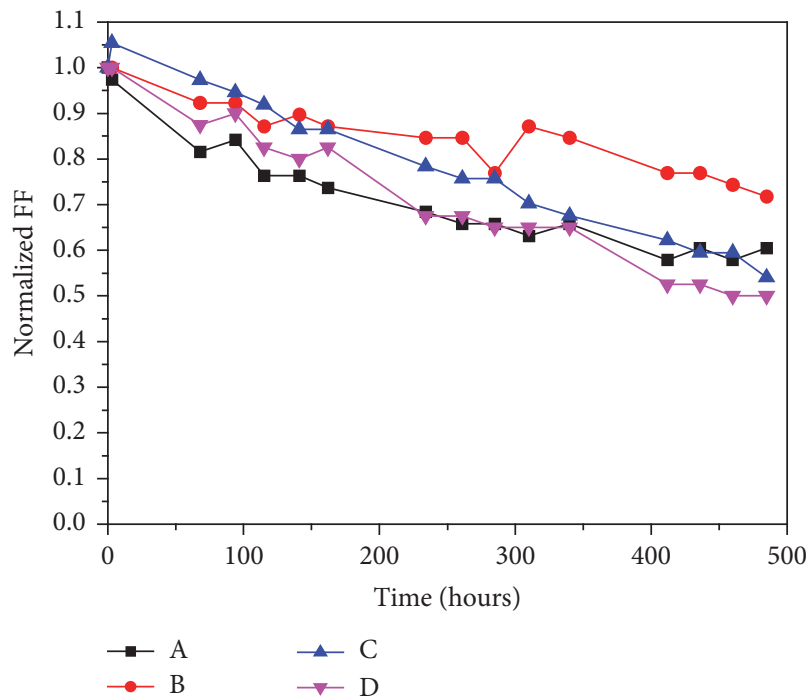

(c)

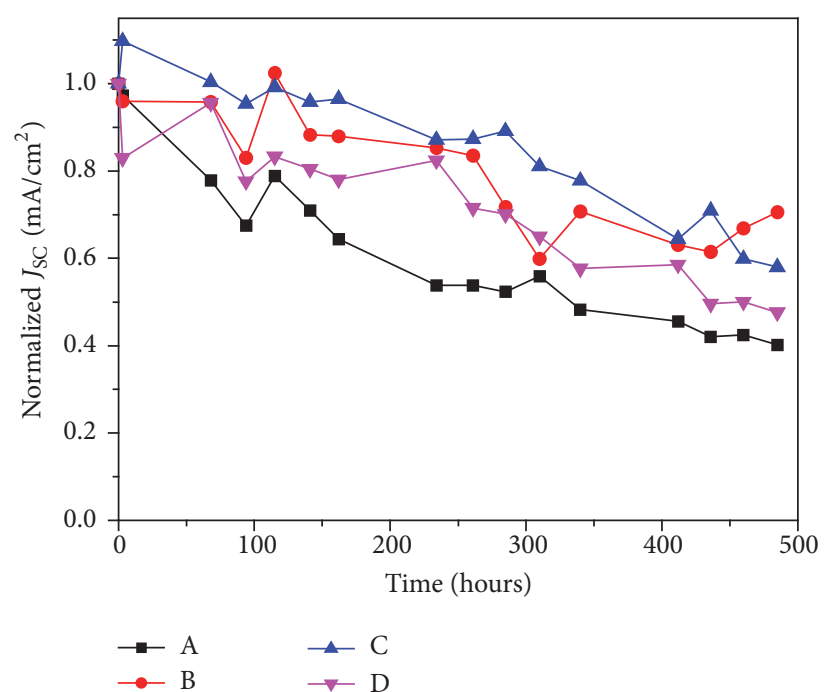

(b)

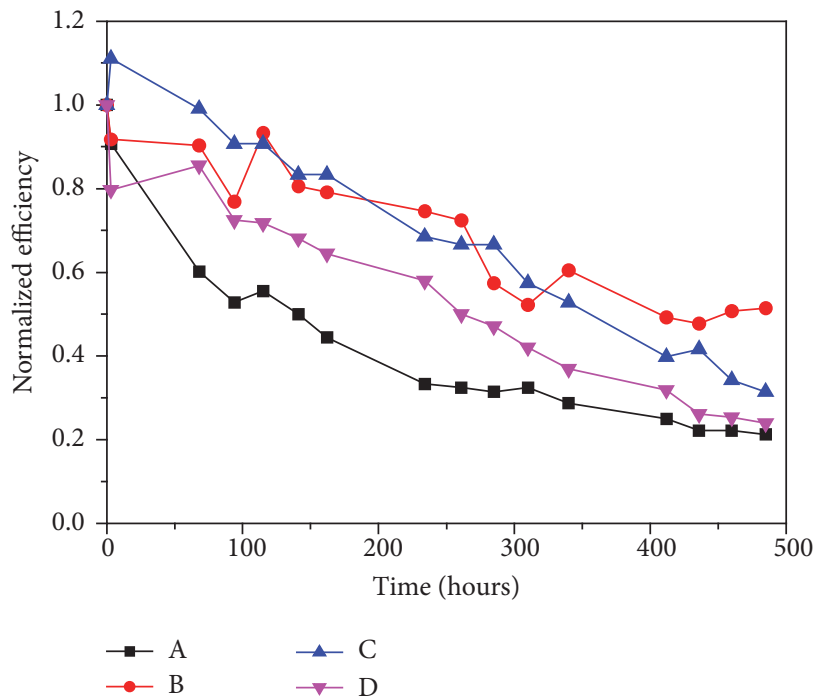

(d)

FIgURE 6: ISOS-L-1 study of PCPDTTBTT solar cell under standard solar irradiation of $100 \mathrm{~mW} / \mathrm{cm}^{2}$ (AM 1.5G); (a) normalized $V_{\text {OC }}$ and time plot of PCPDTTBTT solar cell of the following: A: without thermal annealing, B: thermal annealing at $80^{\circ} \mathrm{C}$, C: thermal annealing at $100^{\circ} \mathrm{C}$, and D: thermal annealing at $120^{\circ} \mathrm{C}$; (b) normalized $J_{\mathrm{SC}}$ and time plot of PCPDTTBTT solar cell of the following: A: without thermal annealing, B: thermal annealing at $80^{\circ} \mathrm{C}$, C: thermal annealing at $100^{\circ} \mathrm{C}$, and $\mathrm{D}$ : thermal annealing at $120^{\circ} \mathrm{C}$; (c) normalized FF and time plot of PCPDTTBTT solar cell of the following: A: without thermal annealing, $\mathrm{B}$ : thermal annealing at $80^{\circ} \mathrm{C}, \mathrm{C}$ : thermal annealing at $100^{\circ} \mathrm{C}$, and $\mathrm{D}$ : thermal annealing at $120^{\circ} \mathrm{C}$; (d) normalized efficiency and time plot of PCPDTTBTT solar cell of the following: A: without thermal annealing, B: thermal annealing at $80^{\circ} \mathrm{C}$, C: thermal annealing at $100^{\circ} \mathrm{C}$, and $\mathrm{D}$ : thermal annealing at $120^{\circ} \mathrm{C}$.

annealed $100^{\circ} \mathrm{C}$ showed that grain sizes are about $120 \pm 5 \mathrm{~nm}$. The roughness of PCPDTTBTT:PCBM blends with $100^{\circ} \mathrm{C}$ annealing is about $3.90 \pm 0.5 \mathrm{~nm}$ (Figure $8(\mathrm{c})$ ). AFM of PCPDTTBTT:PCBM blends at annealed $120^{\circ} \mathrm{C}$ showed that some dark points which lead to leakage are current. They are of different dimensions, a width of $150 \pm 5 \mathrm{~nm}$ and depth of $3 \pm 0.5 \mathrm{~nm}$ (Figure $8(\mathrm{~d})$ ). The morphology is rather different than the other temperature; grains which are spoiled dark spots are larger than in the other temperatures. The roughness of PCPDTTBTT:PCBM blends with $120^{\circ} \mathrm{C}$ is about $2.90 \pm$ $0.5 \mathrm{~nm}$.

\section{Conclusion}

In conclusion, we have fabricated four different solar cells, one as a reference cell that was fabricated without annealing. When PCPDTTBTT solar cell was annealed at $80^{\circ} \mathrm{C}$, the current densities and power conversion efficiencies of PCPDTTBTT solar cells increased compared to PCPDTTBTT solar cell without annealing. Thermal annealing with $80^{\circ} \mathrm{C}$ seems to be optimum temperature for the PCPDTTBTT solar cells. Considering the absorption of PCPDTTBTT:PCBM blend films, there are two absorbance maxima which are 518 and 


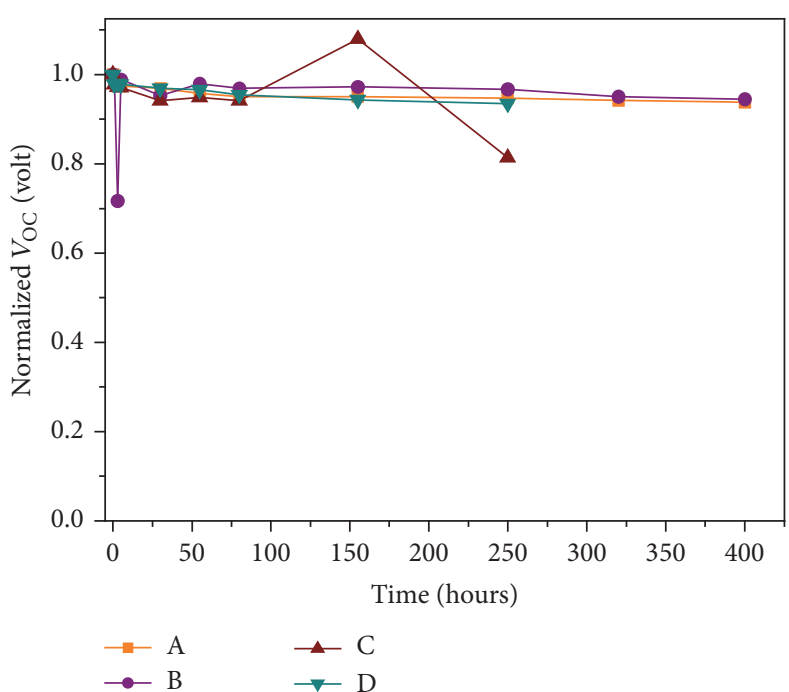

(a)

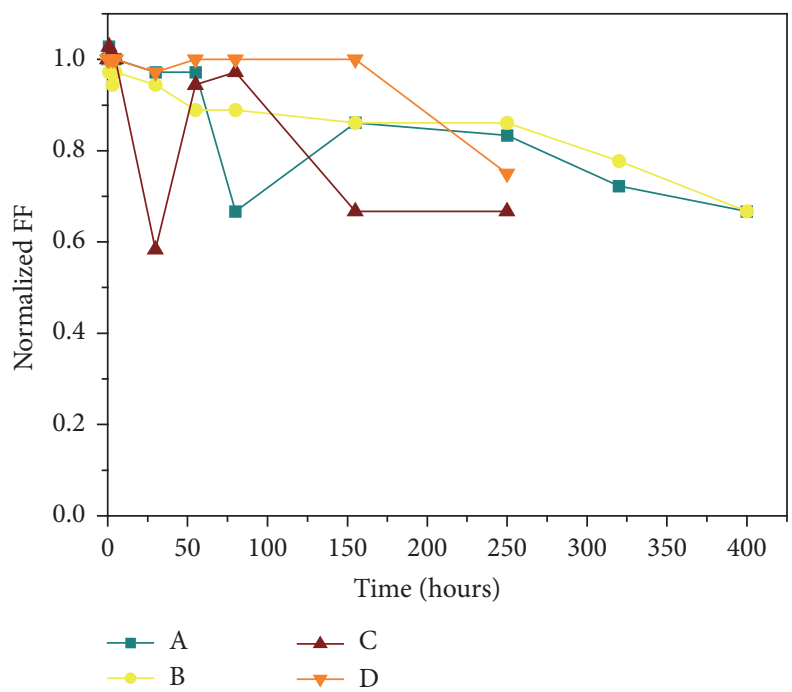

(c)

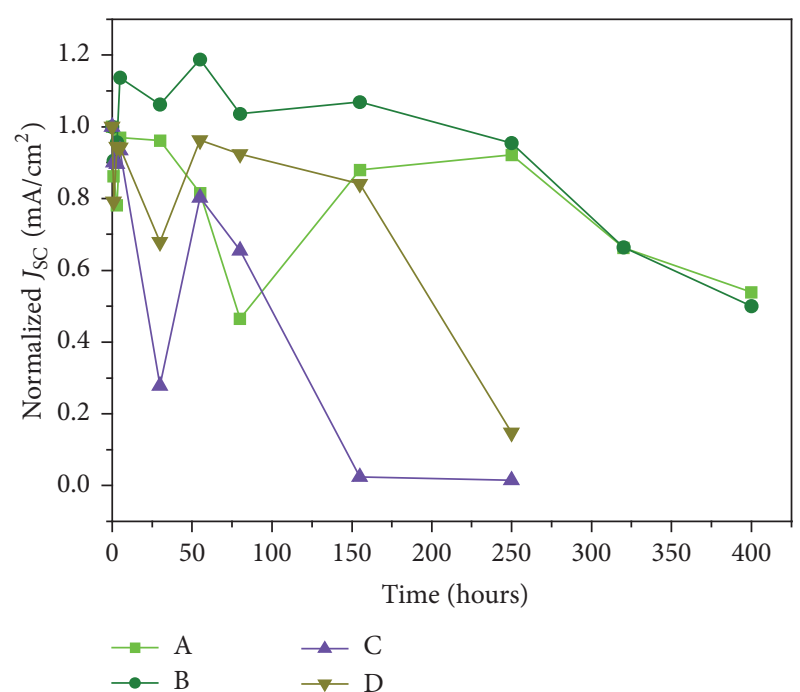

(b)

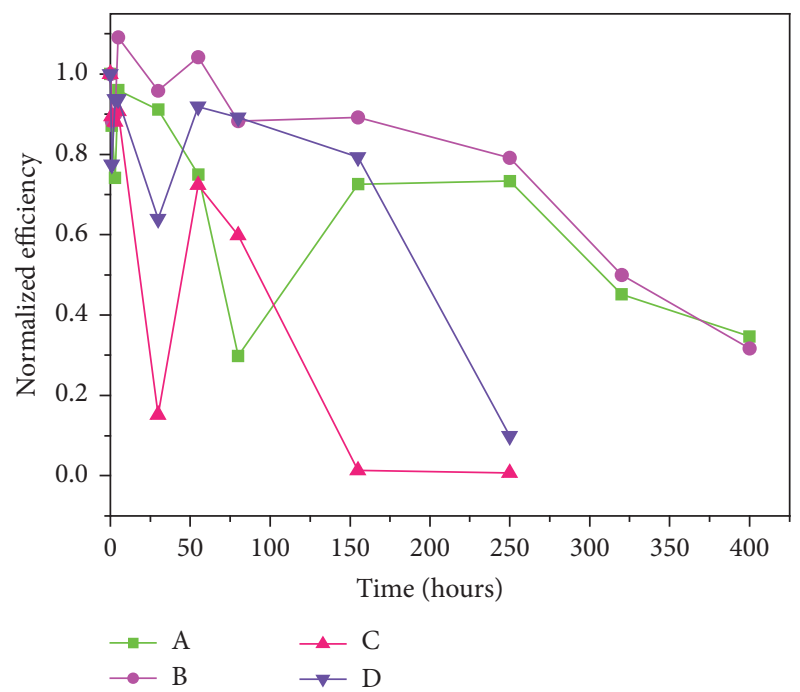

(d)

FIGURE 7: ISOS-D-3 study of PCPDTTBTT solar cell at $65^{\circ} \mathrm{C}$ and $85 \%$ moisture; (a) normalized $V_{\text {OC }}$ and time plot of PCPDTTBTT solar cell of the following: A: without thermal annealing, B: thermal annealing at $80^{\circ} \mathrm{C}, \mathrm{C}$ : thermal annealing at $100^{\circ} \mathrm{C}$, and $\mathrm{D}$ : thermal annealing at $120^{\circ} \mathrm{C}$; (b) normalized $J_{S C}$ and time plot of PCPDTTBTT solar cell of the following: A: without thermal annealing, B: thermal annealing at $80^{\circ} \mathrm{C}$, C: thermal annealing at $100^{\circ} \mathrm{C}$, and D: thermal annealing at $120^{\circ} \mathrm{C}$; (c) normalized FF and time plot of PCPDTTBTT solar cell of the following: A: without thermal annealing, B: thermal annealing at $80^{\circ} \mathrm{C}, \mathrm{C}$ : thermal annealing at $100^{\circ} \mathrm{C}$, and $\mathrm{D}$ : thermal annealing at $120^{\circ} \mathrm{C}$; $(\mathrm{d})$ normalized efficiency and time plot of PCPDTTBTT solar cell of the following: A: without thermal annealing, B: thermal annealing at $80^{\circ} \mathrm{C}$, C: thermal annealing at $100^{\circ} \mathrm{C}$, and $\mathrm{D}$ : thermal annealing at $120^{\circ} \mathrm{C}$.

$643 \mathrm{~nm}$. Absorption of all PCPDTTBTT:PCBM blend films with thermal annealing indicated improved absorption values so photon harvesting increased. UV spectrum of PCPDTTBTT:PCBM blend films with $80^{\circ} \mathrm{C}$ annealing showed that best absorbance's values are increased with annealing with $80^{\circ} \mathrm{C}$ compared to PCPDTTBTT:PCBM blend film without annealing. ISOS- $L-1$ study of PCPDTTBTT:PCBM solar cells with $80^{\circ} \mathrm{C}$ thermal annealing indicated that thermal annealing had improved stability of PCPDTTBTT solar cell. Normalized efficiency increased to $50 \%$ durability from $20 \%$ durability during $500 \mathrm{~h} . T_{80}$ value of PCPDTTBTT solar cell changed drastically from 10 hours to 150 hours. $T_{80}$ value of P3HT (commercial polymer) and solar cell $T_{80}$ value are $235 \mathrm{~h}$ [19-21], so the results are indicating that PCPDTTBTT is very promising material since stability is very close to P3HT. In addition, PCPDTTBTT solar cell showed $70 \%$ durability after $250 \mathrm{~h}$ in $I S O S-L-1$ tests. Accelerated aging tests at $85^{\circ} \mathrm{C}$ and ISOS-D-3 test also indicated that the stability of PCPDTTBTT solar cells under prolonged thermal and moisture stress is about $400 \mathrm{~h}$. 


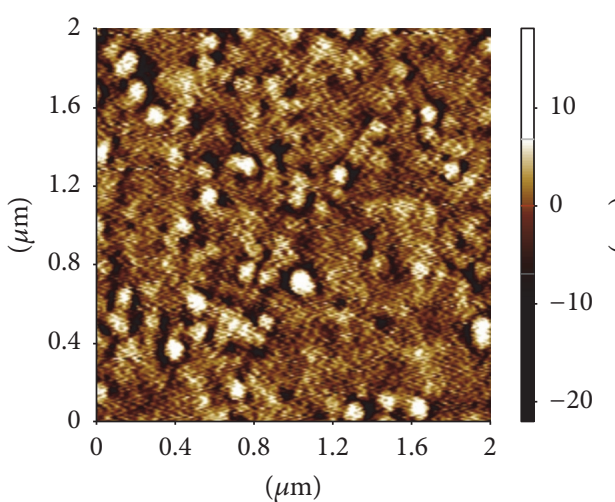

(a)

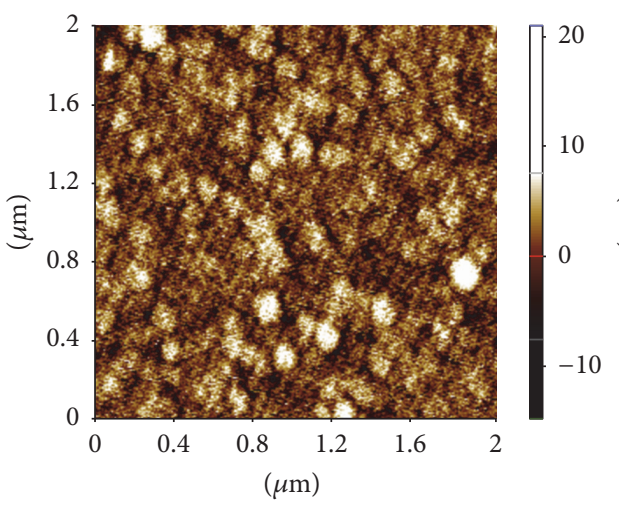

(c)

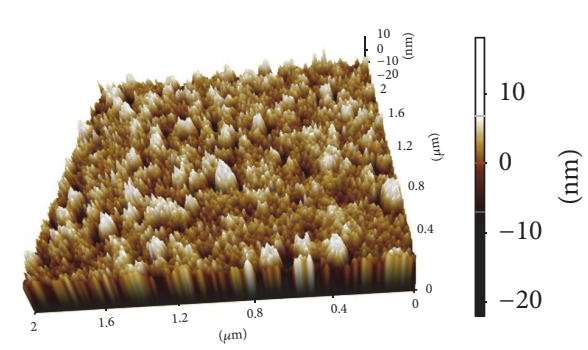

(e)

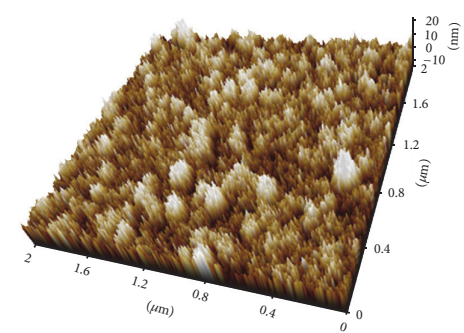

(g)

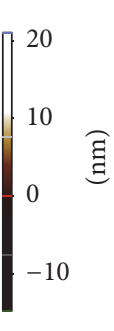

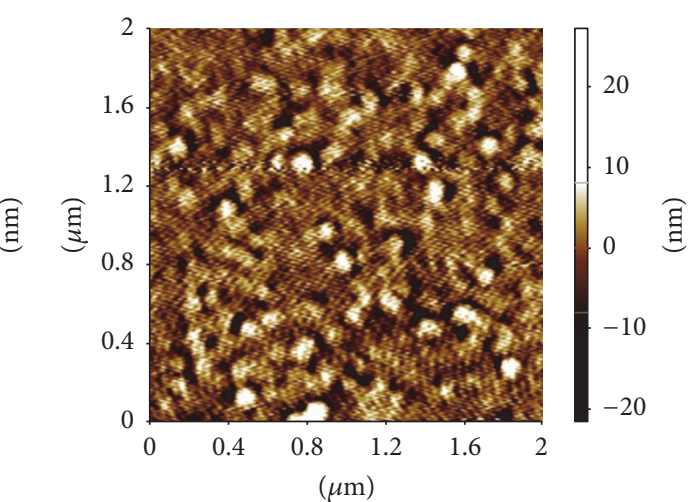

(b)

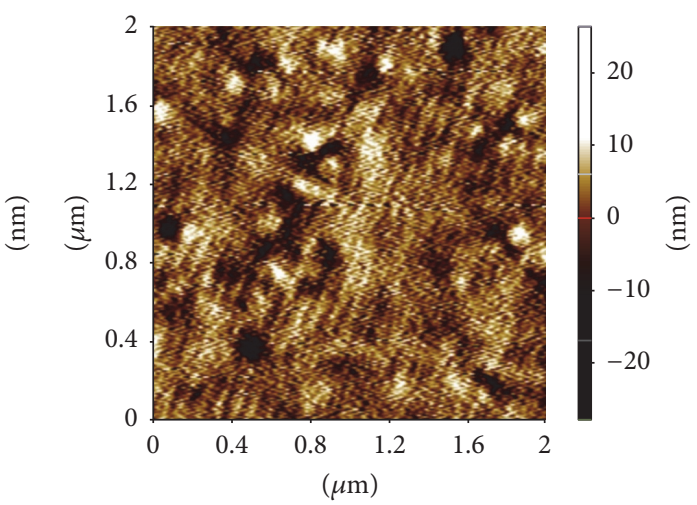

(d)

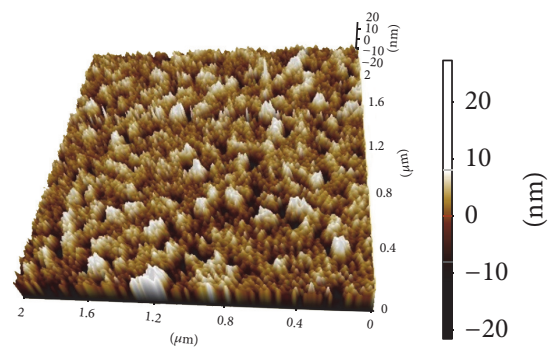

(f)

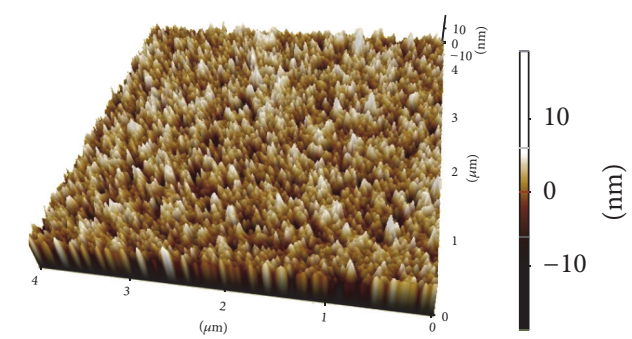

(h)

FIgUre 8: AFM topography spectra of PCPDTTBTT:PCBM blends annealed at different temperatures of $80^{\circ} \mathrm{C}, 100^{\circ} \mathrm{C}$, and $120^{\circ} \mathrm{C}$ for $10 \mathrm{~min}$ $2 \mu \mathrm{m} \times 2 \mu \mathrm{m}$ scan size: (a) no annealing, (b) being annealed at $80^{\circ} \mathrm{C}$, (c) being annealed at $100^{\circ} \mathrm{C}$, and (d) being annealed at $120^{\circ} \mathrm{C}$; AFM $3 \mathrm{D}$ spectra of PCPDTTBTT:PCBM blends annealed at different temperatures: (e) no annealing, (f) being annealed at $80^{\circ} \mathrm{C}$, (g) being annealed at $100^{\circ} \mathrm{C}$, and $(\mathrm{h})$ being annealed at $120^{\circ} \mathrm{C}$. 
The results showed that the stability of this polymer is good and can be improved with novel encapsulation techniques, for example, atomic layer deposition (ALD) or novel barrier materials.

\section{Competing Interests}

The authors declare that they have no competing interests.

\section{References}

[1] S. H. Park, A. Roy, S. Beaupré et al., "Bulk heterojunction solar cells with internal quantum efficiency approaching 100\%," Nature Photonics, vol. 3, no. 5, pp. 297-303, 2009.

[2] H.-Y. Chen, J. Hou, S. Zhang et al., "Polymer solar cells with enhanced open-circuit voltage and efficiency," Nature Photonics, vol. 3, no. 11, pp. 649-653, 2009.

[3] Y. Liang, Z. Xu, J. Xia et al., "For the bright future-bulk heterojunction polymer solar cells with power conversion efficiency of 7.4\%," Advanced Materials, vol. 22, no. 20, pp. E135-E138, 2010.

[4] S. K. Lee, J. H. Seo, N. S. Cho, and S. Cho, "Effect of side chain position on solar cell performance in cyclopentadithiophenebased copolymers," Thin Solid Films, vol. 520, no. 16, pp. 54385441, 2012.

[5] Y. Zhang, Z. Li, J. Ouyang et al., "Hole transfer from PbS nanocrystal quantum dots to polymers and efficient hybrid solar cells utilizing infrared photons," Organic Electronics, vol. 13, no. 12, pp. 2773-2780, 2012.

[6] A. J. Moulé, A. Tsami, T. W. Bünnagel et al., "Two novel cyclopentadithiophene-based alternating copolymers as potential donor components for high-efficiency bulk-heterojunctiontype solar cells," Chemistry of Materials, vol. 20, no. 12, pp. 40454050, 2008.

[7] E. A. Katz, S. Gevorgyan, M. S. Orynbayev, and F. C. Krebs, "Out-door testing and long-term stability of plastic solar cells," The European Physical Journal Applied Physics, vol. 36, no. 3, pp. 307-311, 2006.

[8] K. Norrman, N. B. Larsen, and F. C. Krebs, "Lifetimes of organic photovoltaics: combining chemical and physical characterisation techniques to study degradation mechanisms," Solar Energy Materials and Solar Cells, vol. 90, no. 17, pp. 2793-2814, 2006.

[9] W. J. Potscavage Jr., S. Yoo, B. Domercq, and B. Kippelen, "Encapsulation of pentacene/ $\mathrm{C}_{60}$ organic solar cells with $\mathrm{Al}_{2} \mathrm{O}_{3}$ deposited by atomic layer deposition," Applied Physics Letters, vol. 90, no. 25, Article ID 253511, 2007.

[10] F. C. Krebs and H. Spanggaard, "Significant improvement of polymer solar cell stability," Chemistry of Materials, vol. 17, no. 21, pp. 5235-5237, 2005.

[11] M. Jørgensen, K. Norrman, and F. C. Krebs, "Stability/degradation of polymer solar cells," Solar Energy Materials and Solar Cells, vol. 92, no. 7, pp. 686-714, 2008.

[12] M. O. Reese, S. A. Gevorgyan, M. Jørgensen et al., "Consensus stability testing protocols for organic photovoltaic materials and devices," Solar Energy Materials and Solar Cells, vol. 95, no. 5, pp. 1253-1267, 2011.

[13] A. C. Mayer, M. F. Toney, S. R. Scully et al., "Bimolecular crystals of fullerenes in conjugated polymers and the implications of molecular mixing for solar cells," Advanced Functional Materials, vol. 19, no. 8, pp. 1173-1179, 2009.
[14] H. Hoppe and N. S. Sariciftci, "Morphology of polymer/fullerene bulk heterojunction solar cells," Journal of Materials Chemistry, vol. 16, no. 1, pp. 45-61, 2006.

[15] W. Ma, C. Yang, X. Gong, K. Lee, and A. J. Heeger, "Thermally Stable, Efficient Polymer Solar Cells with Nanoscale Control of the Interpenetrating Network Morphology," Advanced Functional Materials, vol. 15, no. 10, pp. 1617-1622, 2005.

[16] J. Jo, S. I. Na, S. S. Kim et al., "Three-dimensional bulk heterojunction morphology for achieving high internal quantum efficiency in polymer solar cells," Advanced Functional Materials, vol. 19, no. 15, pp. 2398-2406, 2009.

[17] S. S. van Bavel, E. Sourty, G. de With, and J. Loos, “Threedimensional nanoscale organization of bulk heterojunction polymer solar cells," Nano Letters, vol. 9, no. 2, pp. 507-513, 2009.

[18] B. Roth, A. E. Rudenko, B. C. Thompson, and F. C. Krebs, "Photochemical stability of random poly(3-hexylthiophene-co3-cyanothiophene) and its use in roll coated ITO-free organic photovoltaics," Journal of Photonics for Energy, vol. 5, no. 1, Article ID 057205, 2015.

[19] S. K. Hau, H.-L. Yip, O. Acton, N. S. Baek, H. Ma, and A. K.Y. Jen, "Interfacial modification to improve inverted polymer solar cells," Journal of Materials Chemistry, vol. 18, no. 42, pp. 5113-5119, 2008.

[20] E. A. Parlak, "The blend ratio effect on the photovoltaic performance and stability of poly (3-hexylthiophene):[6,6]phenyl-C61 butyric acid methyl ester (PCBM) and poly(3octylthiophene):PCBM solar cells," Solar Energy Materials and Solar Cells, vol. 100, pp. 174-184, 2012.

[21] B. Zimmermann, U. Würfel, and M. Niggemann, "Longterm stability of efficient inverted P3HT:PCBM solar cells," Solar Energy Materials and Solar Cells, vol. 93, no. 4, pp. 491-496, 2009. 

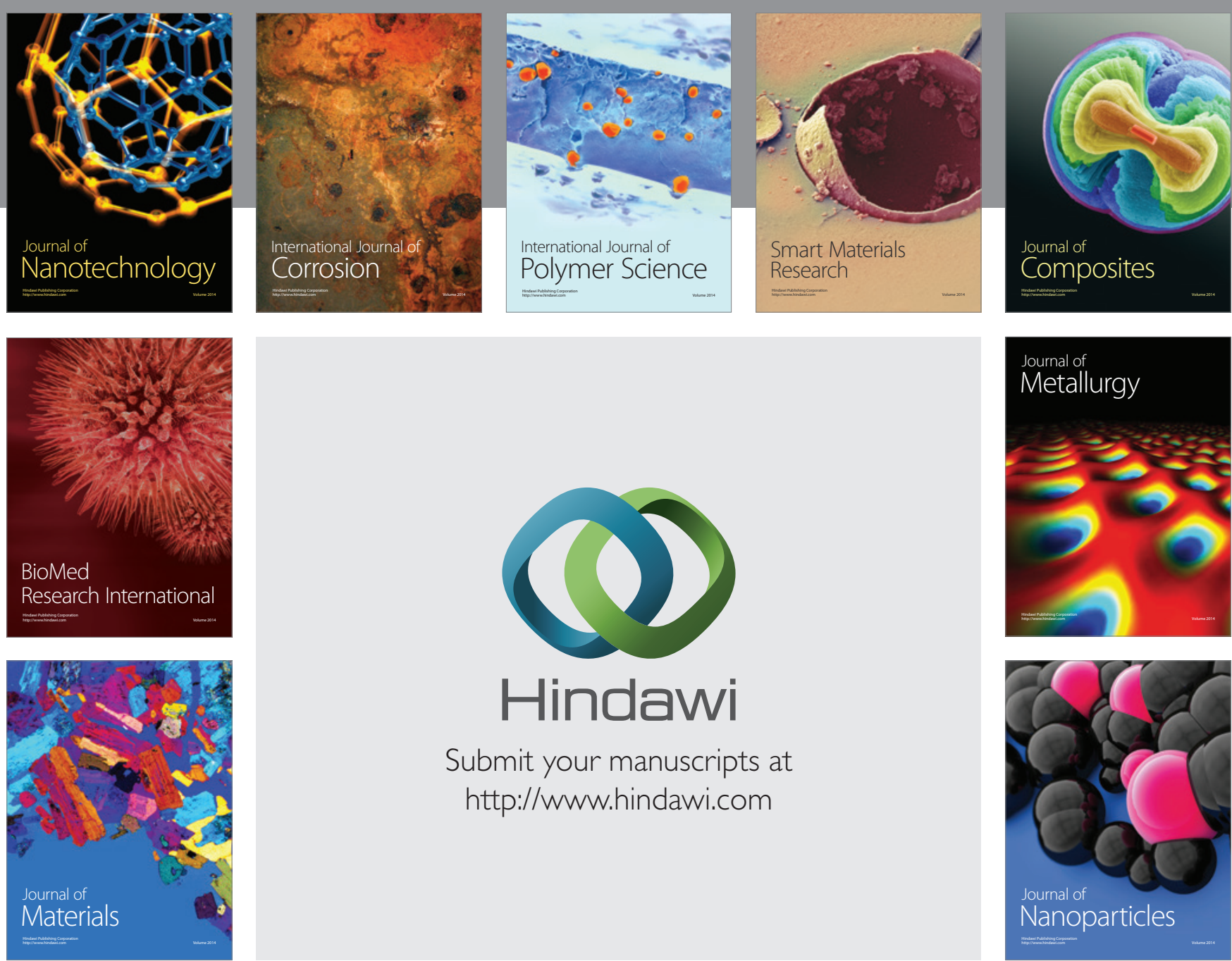

\section{Hindawi}

Submit your manuscripts at

http://www.hindawi.com

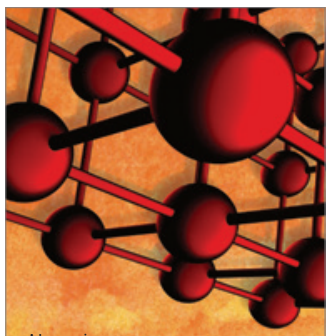

Materials Science and Engineering
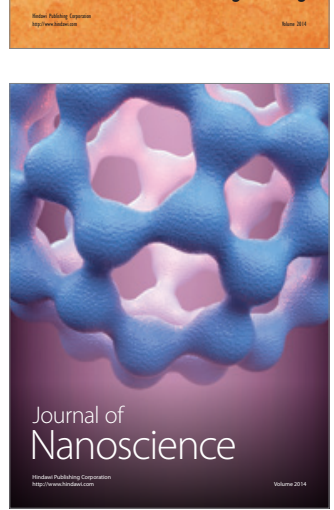
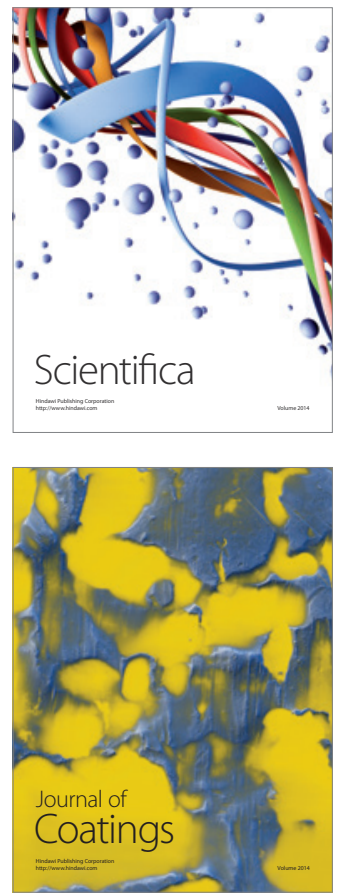
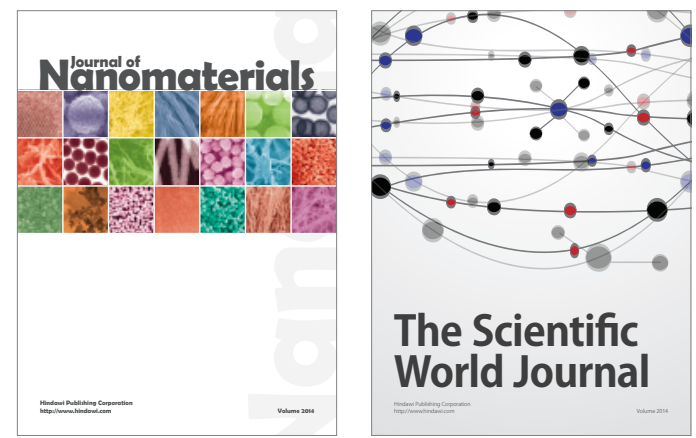

The Scientific World Journal
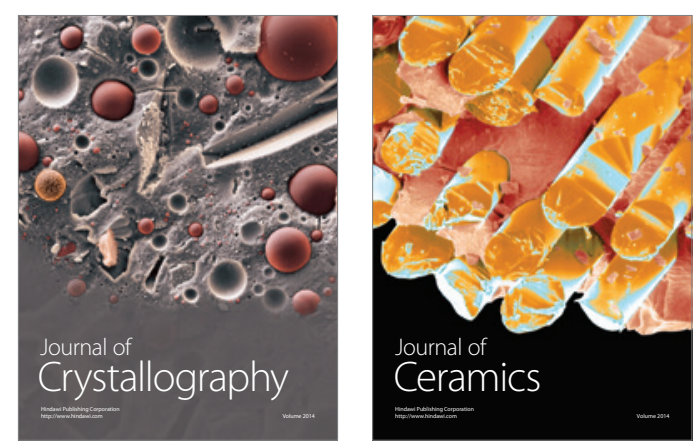
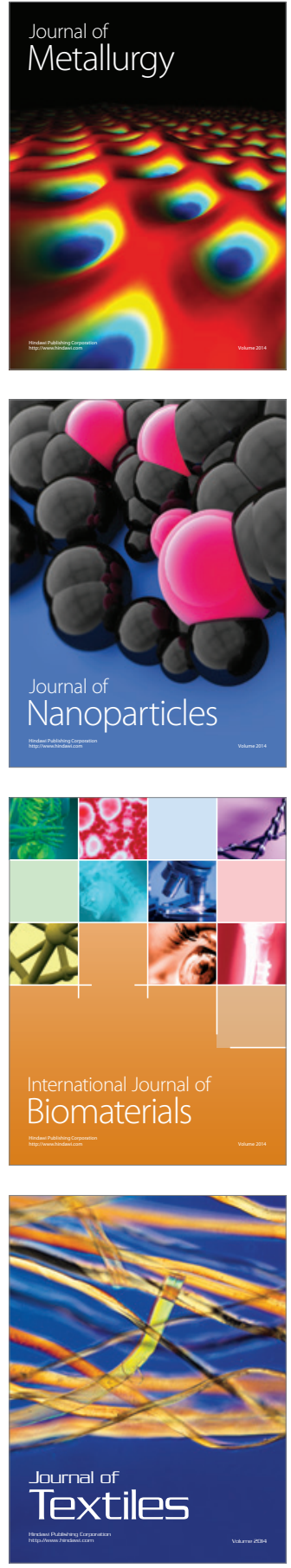